\title{
Geoffrey Benjamin
}

Temiar Religion 1964-2012. Enchantment, Disenchantment, and Re-enchantment in Malaysia's Uplands. Singapore: NUS, 2014, xix-450. IS BN 9789971697068. Price: USD 42.00 (paperback).

Temiar Religion 1964-2012 is a fascinating monograph not just because of the detailed ethnography the author provides on the Temiar of West Malaysia but also because of the sophisticated overarching concept which underlies the book. It consists of Geoffrey Benjamin's writings (published and unpublished) on issues relating to Temiar religion belief and practice over a period of 40 years, reflecting his long engagement with this Orang Asli group from the moment he was an apprentice ethnographer under the supervision of Edmund Leach until the present. As this neophyte would later become one of the fathers of modern Orang Asli studies, the periodicity of some of the chapters is intriguing as they reflect the intellectual development of the ethnographer. (There is a nice photograph of the young Geoffrey in 1968 sitting in a make-shift hut in what seems to be khaki shorts and climbing boots with his socks pulled up).

The book circles around chapters $3-8$ which formed Benjamin's original 1967 Cambridge Ph.D thesis titled Temiar Religion, and which are published now for the first time. As Benjamin humbly notes in the introduction, the thesis is somewhat dated in the manner of its descriptions, the language used, and theoretical interests, which reflect the structuralist concerns of the 196os and particularly those of his famous supervisor. The thesis is thus presented here somewhat as a period piece with 'warts and all' (Benjamin's words) and reading it in this context makes it a vintage piece that has the effect of taking the reader back to the anthropological climate, as well as to the Temiars of the 1960s. In the body of the thesis all the references are authentic to the period and it is fascinating to note that many of the articles he used at the time and that had just been published would later become classics in their own right. Benjamin also adds contemporary 2014 commentary in the form of footnotes to the thesis providing reflective background information ranging from later reflections, changes in his later thought, as well as references to new knowledge and criticisms of his thesis by later ethnographers. These 2014 footnotes add essential information on the subject, as well as Benjamin's subjectivity. They also provide insight into the development of an important ethnographer as well as the evolution of the field over several decades.

The thesis-chapters deal with Temiar Animic religion. They cover Temiar ideas about taboos and prohibitions in relationship to the environment, species, and people as well as beliefs about what would happen if they were to break. The ethnography is wonderfully detailed. Since the presentation and

(C) NATHAN PORATH, 2016 | DOI: 10.1163/22134379-17201007

This is an open access article distributed under the terms of the Creative Commons 
analysis is structuralist (due to Leach's involvement), the author sees the taboos as based on violations of structured binary opposites. The present day reader would have problems with some of the religious categorical terms the author uses to order and give coherency to the Temiar data in the Ph.D chapters; terms like 'good and evil', 'nature/culture' and 'theology', which can be critically evaluated as problematic for this ethnographic context. Such terms reflect a monotheistic understanding of religion and are undoubtedly part of what Benjamin meant by the 'warts' in the Ph.D chapters. Much of the data might today be read in terms of indigenous ethnopsychology, healing and therapy, indigenous world view and knowledge of the environment. Nevertheless, the Ph.D thesis should have been published in the early 1970 s. Since then there have been at least two well-known monographs (those of Jennings and Roseman) on the Temiar who, although they consulted Benjamin's original Ph.D thesis, produced their data within very different theoretical representations. Benjamin ungrudgingly exhorts us to read his own work alongside theirs, and in later chapters references them as well.

The vintage 'back to the 6os' effect of the thesis-chapters is further shaped by the next chapter 9 which reproduces Benjamin's fieldwork correspondences with his supervisor during his original fieldwork. Some of these correspondences have already been published in Stanley Tambiah's monograph on the life of Edmund Leach and reveal to us how involved his supervisor was in his student's research. The book also reproduces Leach's handwritten comments as well as sketches

The chapters 10-12 continue with Benjamin's analysis of Temiar animisitic and shamanic ideas and experiences and practice. Here Benjamin utilizes a more performative as well as ethnopsyhological approach to the data, influenced by later authors writing on the Temiar. Chapter 11 and 12 are articles which were already published and rather well known within Malay and Orang Asli studies. Chapter 11 comparatively explores the concept of Animistic belief between the Temiar, other Orang Asli groups and Malays. It tries to provide coherency to the animistic diversity of beliefs in the Malay peninsula. Chapter 12 focuses on the relationship between danger and dialectics behind Temiar notions and social experiences of childhood and parenthood. This chapter makes some fascinating ethno-psychological assertions that show how indigenous ethnopsychology is related to animistic belief.

In the last two chapters the author shifts gear to a more sociologically focused approach and discusses Temiar conversions to world religions since the 1970s. Using a Weberian approach of enchantment and disenchantment as well as re-enchantment Benjamin discusses the position of the Bahai religion in Temiar life during the 1970s. During this decade there was a short lived 
moment when some Temiars chose to convert to this monotheistic religion. The author sees this conversion as being the consequence of re-enchantment, within the processes of rationalization that was occurring in Temiar society brought on by the pressures to develop and convert to a monotheistic religion. Chapter 12 extends the description and discussions of Temiar conversion to Islam and Protestantism as well as to the rise and practice of an endogenous Temiar monotheistic religion called Keluj Selamed. Benjamin suggests that the conversion to Islam and Protestantism was not carried out for religious reasons but for socio-economic as well as political reasons. On the other hand, the endogenous monotheistic religion brings together motifs from the customary Temiar beliefs and combines them with monotheist conceptions of a one creator divinity. It is unfortunate that the author could not reveal to us how the various prohibitions and taboos have worked their way into the variety of Temiar monotheistic lifeways and beliefs during the period he calls re-enchantment. The book also has four appendixes two of which provide mid-twentieth century descriptions of Temiar mediumistic practices. In the other two appendixes the author provides ethnographic descriptions of burial practices as well as children's dreams. Although Temiar Religion is not a historical account, one can very easily construct the changes in Temiar social and religious life during the twentieth century. The book is wonderfully illustrated with both color and black and white photographs. Some photos are from the archives, others from the author's fieldwork taken during the 1960 s and yet others from later and more recent visits. There is also a forward written by James C. Scott.

Temiar Religion is anthropology at its best. I believe that for the author it is a work of achievement. This book is a contribution to social sciences on many fronts. It would be of interest to Orang Asli Studies/Malay/South East Asian Studies, the study of animistic belief as well as to the anthropology and sociology of religion, shamanism/healing and indigenous psychology. The book can also serve as a nice contribution to the study of the processes of fieldwork in the construction of ethnography.

\section{Nathan Porath}

Center for Ethnic Studies and Development (CESD), Chiang Mai University nathanporath@yahoo.co.uk 